\title{
Religiøse rødder og ruter mellem øst og vest - cirkulær evolution og hybride spejlinger
}

\author{
JØRN BORUP
}

\begin{abstract}
ENGLISH ABSTRACT: The object of the present article is the transformative processes of religion between East and West. The article analyses the construction of religious traditions as hybrids and products of circular transformations, based on actor networks, practice/teaching and concrete historical contexts. Empirical data and discussions of illustrative metaphors are given to explore also theoretical implications for such flows and circulations.
\end{abstract}

DANSK RESUME: Denne artikel omhandler væsentlige aspekter af transformationen af religion mellem øst og vest. Artiklen analyserer konstruktionen af religiøse traditioner som hybrider og produkter af cirkulære transformationer, baseret på aktørnetværk, praksis/lære og konkrete historiske kontekster. Empirisk data og diskussioner af illustrative metaforer gives til undersøgelse af også teoretiske implikationer af sådanne flows og cirkulationer.

KEYWORDS: religious circulation, transformation, East-West, spirituality, Easternization.

Asiens rolle som økonomisk førerhund har været nogle år under opbygning, men synes efterhånden at have fået så meget plausibilitet, at den kan legitimere relevansen af den mantriske påpegning af det 21. århundrede som 'Asiens århundrede' med sandsynlige transformationer også af kulturel karakter. Transfigurationer mellem 'hård' og 'blød' magt har længe sat sit mærke på den kulturelle økonomi, hvor "the circulation of East Asian cinema, manga, anime, television shows, food, design, and allied areas in East and Southeast Asia" (Duara 2010, 977) længe har været med til at sætte dagsordenen. Da "cultural identities are shaped by circulations of culture, 
knowledge, technology, good services, and finance" (ibid. 983), vil naturligvis også religion spille en fortsat rolle, ikke mindst som aspekt af en sådan cirkulation mellem øst og vest. Denne trafik af "interaktive netværk" (McNeill \& McNeill 2003) mellem religiøse ideer, praksisformer og personer har stået på mellem øst og vest $\mathrm{i}$ århundreder, men med globalisering og et nyt perspektiv for forandret magtbalance fået en ny 'vending'. Ikke bare for religionsforskningen, men for forståelsen af generelle kulturelle transformationer, er analyser af disse nødvendige.

Denne artikel vil analysere sådanne cirkulationer mellem øst og vest inden for religionernes område. Den vil beskrive konkrete empiriske kontekster med relevans for og eksemplifikation af sådanne bevægelser, og den vil med inddragelse af nyere forskningsbidrag i bredere forstand undersøge det teoretiske felt, som sådanne cirkulære transformationer implicerer. ${ }^{1}$

\section{Nye rødder}

Postmoderne og postkolonial kritik af og alternativer til universalia, iklædt eurocentrisk partikularisme og teleologisk historieforståelse, har de sidste par årtier fulgt også religionsforskningen. Traditioner er blevet vendt på hovedet, og uanset fagligt og ideologisk ståsted er det en kritik, ingen religionsforsker kan sidde overhørig. En sådan kritik 'afslører' ikke blot skæve magtforhold mellem 'dem' og 'os', eller mellem beskrevne og beskrivende, men udstiller også faglige skævvridninger. Begrebet 'religion' er, som mange efterhånden har påpeget, i sig selv et begreb, der er indlejret i teorier og med typiske metodologi- og kategoriseringsprincipper, der er født og farvet af protestantiske og eurocentriske rammer og diskurser. ${ }^{2}$ Naturliggørelsen af dette europæisk farvede religionsbegreb har betydet, at religionsbegrebet også uden for sin protestantiske og europæiske kontekst er integreret som del af et almindeligt vokabular. Det samme gælder typisk også for begrebet og disciplinen filosofi; også i Asien forstås dette begreb som udtryk for en (ikke vestlig og dermed partikulær) universalistisk tradition med den underforståede præmis, at Platon og Aristoteles frem for østlige fagkolleger som Nagarjuna og Zhuangzhu studeres som grundlæggere af og repræsentanter for feltet. ${ }^{3}$

Inden for den del af religionsforskningen, der især beskæftiger sig med Asien, er der i dag ikke mange, der ukritisk kan ignorere kritikken og dekonstruktionen af tidligere forskning. Decentraliseringen af Vesten som historiens og universets midte har i mange år været fokus for en række værker, ikke mindst med påpegning af

1 'Øst' bruges her som pragmatisk afgrænset begreb for det geo-kulturelle område fra Indien og østpå; 'vest' bruges om det geo-kulturelle område udgået fra Europa.

2 Navne som Talal Asad, Timothy Fitzgerald, Tomoko Masuzawa og Russell T. McCutcheon har således været fremtrædende kritikere af sådanne forskningspositioner.

3 J. J. Clarke tilskriver på samme måde en sådan "endemic Eurocentrism" (Clarke 1997, 5) at "the role of Eastern thought within the broad Western intellectual tradition has largely been ignored by historians of ideas" (ibid.). 
Asiens bidrag til Vestens egen kulturelle og civilisatoriske udvikling. ${ }^{4}$ Alternativer har således været mødt med 'inter-Asian studies' eller 'sub-altern studies', der forsøger at fravriste sig partikulære referencerammer. Et eksempel på en sådan er antologien The Gaze of the West and Framings of the East, der vil skabe et "discursive space for us who are located in the East (and elsewhere as the non-West) to evaluate the gaze of the West as evident in its narratives on the praxis of Easternization" (NairVenugopal 2012, 6). Sådanne initiativer skal af både faglige og ideologiske grunde hilses velkommen. Flere af disse afspejler dog relativismens egen indbyggede faldgruber: Er af-essentialisering og af-dikotomisering således overhovedet muligt inden for almindelige regler for diskursiv tænkning og argumentation? Det Edward Said'ske projekt og de mange bøger, der er kommet i kølvandet på orientalismekritikken, har ofte været spejlinger af den kritiserede diskurs og taget form af revisionistisk occidentalisme, omvendt orientalisme og nye 'opfundne traditioner'. Dette gælder for både en række vestlige kritikere, der har 'købt' det post-orientalistiske projekt med 'white-male bashing' (Urban 2007, 12), og det gælder 'østlige' positioner, hvis kritik synes at have svært ved at bundfælde sig i andet end nye, ideologiske essentialiseringer. Trods interessante perspektiver og sympatiske strategier synes dette for eksempel at være tilfældet med flere artikler i den ovennævnte antologi.

Et andet perspektiv, der de sidste par årtier har flyttet markant på forskningen omkring 'øst og vest', og som kan ses i forlængelse af ovenstående kritikfelt, men som også har udviklet sig uafhængigt herfra, er den 'genealogiske arkæologi', der søger alternative rødder til religionernes udvikling. Vestens 'opdagelse' af Østens religioner er i sig selv blevet en genre, der har genereret adskillige interessante publikationer. Først oplysningstidens europæiske intellektuelle, der løftede Kong Fuzi (Konfucius) "to almost cult status" (Clarke 1997, 16), og siden romantikkens opdagelse og begrebsliggørelse af 'hinduisme' og 'buddhisme' hører til de store fortællinger (fx King 1999; Clarke 1997). Europæiske filosoffers (fx Voltaire, Leipzig, Schopenhauer, Nietzsche, Heidegger) gæld til asiatisk inspiration markeres sjældent uden for det lille felt af 'komparativ filosofi', 5 men har dog været med til at uddybe forståelsen af de mulighedsbetingelser og historiske kontekster, moderne tænkning har været underlagt.

Et nyere værk bør her fremhæves, som har været med til at flytte de historiske rammer for sådanne møder, nemlig Urs Apps The Birth of Orientalism (App 2010). I

$4 \quad$ Eksempelvis kan nævnes Lach 1994; Lach \& van Kley 1998; Goody 1996; Hobson 2004. Goody nævner fx, at Vesten først med renæssancen og for alvor med industrialiseringen kan siges at have genereret en markant ledende position som civilisation. Frem for kulturelle eller religiøse koder som garant for en lineær historie eller dikotomisk øst-vest-forhold foreslår han historiske tilfældigheder og materielle/kulturelle oscillationer som baggrunde for symbiotiske forandringsprocesser inden for et større Eurasien. Man kunne hertil nævne kolonialisme som væsentlig faktor i forskelle i magtforhold. I en anmeldelse af en hard core, bevidst eurocentrist (Ricardo Duchesne) fremfører Hinde det cirkulære (og ikke sjældent fremførte) fundament for skæve magtbalancer: "The West is best because it dominates the world and it dominates the world because it is best" (Hinde 2012, 193).

5 Eksempelvis Larson \& Deutsch 1988 samt tidsskriftet Philosophy East and West. 
denne flyttes centrum for 'opdagelsen' et par århundreder tilbage, nemlig til især jesuitiske missionærers møder med kinesiske og japanske kulturer og religioner. Bogen lægger samtidig op til at være et opgør med det paradigme, der siden 1990'erne har bredt sig indenfor buddhismestudierne (fx Lopez 1995), nemlig at buddhisme er 'opfundet' i det 19. århundrede og at 'opfinderne' i høj grad har været kolonisatorernes forlængede arm. I modsætning til denne enstrengede opfattelse hævder App, at missionsarbejdet og det senere dialogperspektiv i høj grad også var konstruktivt medkonstituerende for senere vidensproduktion inden for rammen af 'opdagelsen af Asien'. Allerede i 1574 havde jesuitter i Japan således påbegyndt fortolkning af kinesiske versioner af Lotus-sutraen. Men også bibel-inspirerede narrativer og tanker om 'ur-tradtioner' var med til at konstruere 'orientalske systemer', der i dag forekommer ganske spektakulære (fx at ægyptisk var oprindelse til buddhismen, og at græsk filosofi havde sin oprindelse i Indien), men som ikke desto mindre på længere sigt var med til at lægge grund til den senere religionshistorie. Dette gælder også Voltaires inspiration fra skriftet Ezour-Vedam, som han kunne bruge i sin kirkekritiske fascination af orientalske traditioner, hvilket i sig selv skulle få betydning for europæisk 'indomani'. Skriftet viste sig dog ikke at være en 'brahminsk ur-tekst og en af de ældste manuskripter i verden' (App 2010, 55), men en produktion fra en europæisk missionærs hånd, en simulacrum med effekt for Voltaires tænkning. I en senere bog har App (2011) fokuseret på et bestemt aspekt af en sådan 'opdagelsesproces', i hvilken buddhismen som negativ 'tomhedskult' blev del af en generel opdagelse af orientalsk filosofi. I det hele taget er begge bøger med til at understrege relevansen af studier i områder, hvor også fejl, misforståelser og bevidste konstruktioner viser sig at have fået konkret mentalhistorisk og politisk betydning, og som derfor skal tages alvorligt af forskningen.

Mens der således nu findes en del kilder til belysning af denne periode (16. til 19. årh.), er tidligere religionsmøder mellem øst og vest stadig et underbelyst emne, ikke mindst på grund af manglende kilder. Mødet mellem gnosticisme og østlige religioner og mellem græsk og orientalsk filosofi er således naturlige emner for sådanne studier. Mens analogier er åbenbare og "cry out for explanation" (Clarke 1997, 38), gælder det for også de mange spekulative bud på mulige inspirationskilder fra Østen til kristendommen, at genealogier er noget mere udfordrende at anskueliggøre. ${ }^{6}$ Robert Bellahs (2011) bud på en evolutionær religionshistorie illustrerer vanskelighederne ved så ambitiøse projekter, men også mulighederne for at grave dybere spadestik i verdenshistorien. Et fornyet fokus på især aksetids-religioner kan netop være en nøgle til både at forstå sociale, kulturelle og filosofiske udviklinger i et bredt, komparativt sigte (Bellah and Joas 2012). Ligesom socio-økonomiske udviklinger kan generere multiple moderniteter, kan man i historien anskue parallelle ruter i øst og

6 Feltets fordring af såvel dybe kundskaber i enkelttraditioner som kompetence i diverse sprog og komparative studier begrænser muligheden for milepæle inden for forskningen, men giver til gengæld råderum for spekulative projekter. Et af disse er Jesusisbuddha.com, en hjemmeside skabt og redigeret af en tidligere dansk buddholog. 
vest (Goody 2010, 94), som er udtryk for 'independent invention' (ibid., 50) og som i bredere forstand altså kan tænkes at udgøre konvergente, eller parallelle evolutionsmønstre.

\section{'Easternization'}

Et mindre ambitiøst projekt, men dog indenfor samme perspektiver for øst-vestmøder, har Colin Campbell analyseret med begrebet "Easternization" (Campbell 2008) om Østens religiøse og kulturelle indflydelse på Vesten specielt siden 1960erne. Campbells mangeårige arbejde med 'østliggørelsen af Vesten' har ikke bare begrebsliggjort et fænomen, som andre på forskellig vis og med forskellige vinkler tidligere har fokuseret på. Det tegner også konturerne til at kunne blive en grand theory med relevans for flere fagfelter, ikke mindst studiet af religion. Tesen går kort sagt ud på at 'vesten' i moderne tid bevæger sig væk fra sin egen kerne til fordel for massiv indflydelse fra 'østen'.

Metoden til at understøtte en sådan tese tager udgangspunkt i Campbells Weberinspirerede, typologiske opdeling i østlige og vestlige civilisationer og religioner. Han lægger meget lidt vægt på den østlige 'type' (hvilket i lyset af den enorme spændvidde er forståeligt, men ikke mindre problematisk), men beskæftiger sig med at se manifestationer af empiriske eksempler på Vestens egen historie og 'østliggørelsen' af Vesten. Således er hele feltet med new age og spiritualitet (herunder yoga, meditation, alternativ helbredelse etc.) et ganske godt indicium på, hvordan østlige traditioner har vundet indpas som væsentlige dele af moderne, vestlig religion og kultur, ja (i dens blanding med psykoterapien) som både årsag til og konsekvens af nedgangen i "traditional Western worldview" (ibid. 96). Østliggørelsen (eksemplificeret ved 'yogaisering' og 'guruisering' som udtryk for omvendt 'Coca-colonization' og McDonaldization', ibid. 20), er derfor også "a process of de-Westernization" (ibid. 41). Disse fænomener bliver overbevisende kontekstualiseret med historiske referencerammer, der strækker sig fra tidlig esoterisme og via beatgenerationen i 1950'erne til 1960'ernes hippiekultur, som udgør det historiske knudepunkt if. Campbells tese. Bevægelsen fra øst til vest understøttes desuden af en intern udvikling, hvor affortryllelse, afmytologisering, moderne teologi, sekularisering og videnskabeliggørelse åbner dørene for den østlige indflydelse, og som retrospektivt får de to traditioner til at passe som hånd i handske. Østliggørelsen hænger altså tæt sammen med en fundamental revolution i vestlig civilisation på niveau med renæssancen, reformationen og oplysningen (ibid., 41), der nok sættes i bredere sociologisk perspektiv med reference til bl.a. Paul Heelas' spiritualiseringsteorier og Steve Bruces sekulariseringsteori, men interessant nok ikke til Charles Taylor's teori om den subjektive vending.

Det historiske og videnssociologiske felt er interessant og relevant og til tider provokerende. Der er imidlertid to typer argumenter og sammenhængen mellem disse, som burde diskuteres, nemlig henholdsvis genealogi og analogi. Den genealogi- 
ske påpegning af metonyme relationer mellem øst og vest er indlysende. De mange empiriske eksempler med ideer, praksisformer, institutioner og aktører, der faktisk dokumenterer konkrete berøringer, er overbevisende. Vestens new age og spiritualitet, beatnikkernes og hippiernes idealer, samt utallige eksempler på religion, filosofi, kunst, arkitektur, litteratur etc. understreger ganske uproblematisk en sådan østlig inspirationskilde. Mere problematisk bliver det, når argumenterne baseres på analoge slutninger på paralleller. Hvorfor er det lige, at visse fænomener som holistisk naturforståelse, dyrerettigheder og økologi er evidens for Easternization, og hvad er det, der gør, at noget er "Eastern in character" (Campbell 2008, 146, 363), i modsætning til angiveligt "quintessentially Western values and beliefs" (ibid. 7)? Hvad gør det plausibelt at hævde, at der er en "fundamental East-West divide" (ibid. 58)? I det hele taget kan man sige, at typologiseringen halter i forhold til empirien, med unødvendige generaliseringer, stereotypiseringer og ind i mellem også romantiseringer (af 'østen') til følge. Dette har Campbell dog taget forbehold for ved både at have et helt kapitel, der diskuterer og svarer på forskellige kritikpunkter, og ved at understrege, at bogen omhandler Vesten, og ikke Østen (ibid., 3). Bogen, der bestemt er både relevant og inspirerende, undersøger med andre ord diffusion, frem for konvergent evolution og parallel udvikling, men fokuserer på envejs-transmissionsmønstre, frem for cirkulation.

\section{Fra rødder til ruter}

Monolitiske transmissionskanaler og enstrengede evolutionsteorier kan være udtryk for et paradigme inden for religionsforskningen, som flere forskere har kritiseret, nemlig fokus på oprindelser, essenser og rødder. Antropologen James Clifford var en af de antropologer, der ville gøre op med en sådan tradition ved at omformulere forskningsobjektet (og teorier/metoder forbundet hermed) fra rødder (roots) til ruter (routes) (Clifford 1997). På samme måde taler Duara (2010) om den historiske cirkulation, der som forklaringsmekanisme kan være med til at se et bredere perspektiv på kulturel og videnssociologisk udvikling. Samme rutemetafor ligger bag David Chidesters ide om "intercultural relations of production" (Chidester 2003, 275)7, ligesom Peter van der Veer omkring øst-vest-sammenhæng taler om en "universalization of ideas that emerges from a history of interactions" (Van der Veer 2009, 1099).

Mens flere forskere inspireret af post-moderne tilgange har abonneret på fuld dekonstruktion med dertilhørende begrebsnegation ('religion', 'kultur', 'øst', 'vest' etc.), fører en anti-essentialisme med fokus på flydende, konstruerede og performede identiteter og traditioner naturligvis ikke nødvendigvis en sådan radikal position med sig. På sin vis kan man sige, at helt traditionel religionshistorisk viden netop bifalder indsigter i religioners og kulturers dynamiske struktur, hvor forandring, udvikling

7 "We are all entangled, implicated, and one way or another engaged in the same history" (Chidester 2003, 276). 
og tilpasning hører til de territorier, forskellige landkort kan hjælpe til at navigere i. Det er i den forstand også helt ukontroversielt, når Thomas Tweed postulerer, at der i religionernes verden er hybrider "all the way down" (Tweed 2002, 19) og at der ville være meget lidt at studere, hvis vi kun interesserede os for "originaler" udenfor cirkulationernes forandringsprocesser. Fremfor defensiv negation, foreslås der således her at anskue, hvordan hybrider og ideer, begreber, kategorier og konstruktioner i sig selv har konkret kulturel, religiøs og ind i mellem også politisk betydning og indflydelse. Analoge og ko-evolutionære transformationer kan således anskues som paralelle udtryk for interaktive og cirkulære transformationsprocesser.

Nogle eksempler fra religionshistorien kan illustrere sådanne udtryk for forandringer, baseret på møder mellem dem og os, mellem øst og vest, mellem forskning og forskningsobjekt. Begreberne 'religion', 'kultur', 'filosofi', 'mystik' og 'spiritualitet' er opfundet og formuleret i vestlige kulturer, men er antaget også uden for den vestlige verden - med lokale sproglige udformninger og dertilhørende virkning. 'Religion' blev fx importeret og operationaliseret i Japan som shūkyō for derefter at blive eksporteret til Kina som zongjiao - begge med politisk betydning for, hvordan de 'religiøse' traditioner har kunnet legitimere og manifestere sig. 'Spiritualitet' og 'mystik' blev af toneangivende vækkelsesprædikanter (som Vivekananda og Dharmapala) i Indien og Sri Lanka importeret som begreber også til post-kolonial identitetskonstruktion, ligesom dikotomier mellem 'vestens materialisme' og 'østens spiritualitet' i både øst og vest blev del af større kulturelle narrativer. Ikke mindst vestlig psykologisering, afmytologisering, videnskabeliggørelse, tekstualisering og evolutionistisk religionsforståelse blev indoptaget og del af neo-hinduistisk og neobuddhistisk diskurs, hos sidstnævnte begrebsliggjort som 'protestantisk buddhisme' (Gombrich \& Obeyesekere 1988). ${ }^{8}$ Perennialismens ide om forskellige mystiskspirituelle adgange til samme transcendente virkelighed var en ide (måske fostret $\mathrm{i}$ det 15. årh.), der for alvor fik vind i sejlene i det 19. årh. takket være disse øst-vest møder, og som ligger bag megen underforstået filosofi i samtidens spirituelle miljøer.

Selv i modernitetskonstruktioner, hvor modstand mod 'vesten' har været italesat, var sådanne diskurser typisk spejlbilleder af vestlige narrativer. Pan-arabisme og kommunistisk anti-vestlig, religionsforståelse var inspireret af totalitære vestlige ideologier (Buruma \& Margalit 2004) og fundamentalismer blev konstrueret via vestlige modernitetsdiskurser. Pan-asiatiske 'strategiske essentialismer' anvendte ofte lignende spejlvendte narrativer til at distancere sig fra 'vesten', blandt andet ved hjælp fra social-darwinistiske modeller vendt på hovedet i nationalistiske og kulturalistiske diskurser. Men ofte blev disse også brugt til at tilpasse sig og udvikle sådanne. Ved at 'grave dybere' afsløres ikke blot, at disse er 'opfundne traditioner', men også, at de er baseret på cirkulationer mellem narrativer. Således er ophøjelse af Bhagavadgita til 'hinduismens Bibel' udtryk for et moderne (protestantisk) tekstuali-

8 Spiritualitet var "indeed a modern concept born out of the interaction between India and the West" (Veer 2009, 1110). 
seringsparadigme, ligesom de strategiske kategoriseringer af konfucianisme som 'rationel religion' og daoisme som 'mystik' er udtryk for narrativer primært opfundet i Vesten, men overtaget af Østen. En interessant historie er ikke mindst, hvordan (moderne forståelse af) yoga er blevet delvist konstrueret i Skandinavien. Før 1920'erne var yogaen således ikke relateret til helse i Indien; men via svenskeren Pehr Henrik Ling (1766-1839 og senere danskeren Niels Buck, 1880-1950) blev yoga del af en kropsliggjort praksis uden relation til religion (Singleton 2010, 84ff.). ${ }^{9}$ På samme måde har Robert Sharf påpeget, hvordan buddhistisk meditation (især zen og vipassana) som udtryk for en mental og erfaringsbaseret teknik (frem for en ritualiseret klosterpraksis) er en modernitetskonstruktion, baseret på østlige vækkelsesbehov og vestlige øst-romantikere (Sharf 1995). ${ }^{10}$ Universaliteten og autenticiteten ved 'spirituelle erfaringer' lader sig relativisere ved påpegning af brugernes fælles narrative konstruktioner - i hvilke også populært formidlede bøger som Zen and the Art ofgenren fungerer som skabelon med prædefinerede autenticitetskriterier.

I moderniteten har kombinationen af rationalitet og spiritualitet ved især buddhisme-receptionen lagt grund til også moderne new age ideer og praksisformer. Selv-udvikling (frem for selv-afvikling) er blevet den gældende praksis og narrativ for vestlig selv-spiritualitet, der ikke mindst via psykologisering af religion nærmest har taget patent på og koloniseret asiatiske traditioner. En indflydelsesrig og kritisk bog om den neo-liberale markedsliggørelse af feltet har derfor den dækkende titel Selling Spirituality (Carrette \& King 2005).

Trods buddhismens generelle image i Asien som en traditionel kulturreligion og selv om østligt inspireret genfortryllelse i Vesten paradoksalt nok følger en modsat tendens til affortryllelse i Asien (Lee 2003) - synes der også at være en parallel tendens til i Asien at lade sig genfortrylle af en 'vestliggjort' version af asiatiske, religiøse traditioner. Yoga (Alter 2004), meditation, feng shui, reiki og alternativ medicin er således også kommet på det østlige marked i sin transformerede, 'vestlige' form som en type "return globalization" (Frøystad 2009, 279). New age og spiritualitetsfeltet i Japan er stærkt inspireret af en vestlig (især amerikansk) tradition, hvorfor yoga i Japan ikke er fra Indien, men fra USA (Borup under udgivelse). Spiritualiseret Dalai Lama-buddhisme er blevet del af tibetanske munkes selvforståelse i Vesten, ligesom den som narrativ former unge inderes forståelse af buddhismen, som alternativ til forældrenes 'kulturbuddhisme', ${ }^{11}$ og i Korea har amerikanske zen-mestres stadfæstelse af koreansk buddhisme gjort denne populær (Joo 2011). I Indien er ayurveda kommet tilbage i sin vestligt transformerede form (Newcombe 2012, 208), og yoga og meditation er i sin 'spiritualiserede' form del af også sekulær erhvervsledelse (Veer 2009, 1116). I Kina genoptages taiji og qigong som spirituel praksis, ikke

9 At Ling i øvrigt selv var inspireret af østlig kampkunst, er yderligere med til at signalere cirkulationsprincippet.

10 "What many Americans and Europeans often understand by the term 'Buddhism', however, is actually a modern hybrid tradition" (McMahan 2008, 5).

11 Referencen til Ladakh er fra Elizabeth Williams Ørberg, der i 2014 afleverer ph.d.-afhandling om emnet. 
mindst via Hong Kong og hovedlandets filmindustri (ibid), og daoisme reintegreres som universel og spirituel tradition, efter at have været i USA (Newcombe 2012, 208). Flere vestlige firmaer (heriblandt det danske the Potential Project) eksporterer mindfulness-kurser til asiatiske lande, og en tamil fortalte mig, at han havde iværksat kurser i yoga og mindfulness for andre srilankanske (og buddhistiske) immigranter i Canada, uanset at han som hindu ikke havde megen baggrund i buddhistisk meditation. Også Østen er således blevet 'østliggjort' med spiritualisering og 'coolnessification' af Østens traditioner som en pendant til og del af en bredere globalisering. Selv om der også er Zen Cafe' i Shanghai, en Zen butik i Yangon og en smart tøjbutik i Bangkok med navnet Zen, synes der dog også at være grænser for, hvor bredt sådanne narrativer kan brede sig (Borup under udgivelse). Zen er i Japan ikke så spirituelt salgbar som i Vesten (ibid.), hvor den af japanske zen-buddhister længe har været spået en bedre fremtid (Dessi 2013, 80), måske netop som udtryk for "globalization in forms that are independent from direct proselytizing and the acquisition of growing membership overseas" (ibid. 88). Man må desuden formode, at der endnu er et begrænset publikum til 'Peter Plys og hans tao' i Kina.

\section{Transmission og transformation; metaforer og katalysatorer}

Historikeren Meyer Abrams argumenterede for, at kunstnere før romantikken så sig selv som et spejl, der reflekterer og imiterer verden, i modsætning til romantikeren, der snarere så sig som en lampe, der illuminerer noget nyt gennem kunstnerens unikke, ekspressive vision (se McMahan 2008, 119-120). David McMahan argumenterer for, at en sådan ekspressiv kunstforståelse, hvori kunstneren 'afslører' virkelighedens dybder som en "epiphanic' understanding of art" (ibid. 146) og samtidig via indsigt og indfølelse udtrykker spontan kreativitet og originalitet, er udtryk for en moderne og vestlig konstruktion (ibid. 139). ${ }^{12}$ Spejlet kan dog også udvides til at være metafor og katalysator i et interaktivt cirkulationsprincip, der både afspejler og genererer diskurser og traditioner, i hvilke transformation fremstår som et "corrective mirror" (Clarke 1997, 28) via spejling af en selv og andre i en række lettere forskudte spejle, hvis placering muliggør ikke en hermeneutisk cirkel, men en evolutionær spiral. ${ }^{13}$ Det er i den forstand indlysende, at netop kunst blev en bærer af spiritualitet, der kombinerede østlige og vestlige traditioner og "deeply influenced an entire spectrum of thinkers ranging from Heidegger to Jung" (Veer 2014, 52). Mens en 'vinduemetafor' (virkeligheden anskues uden filtre) eller en lysmetafor (virkeligheden illumineres via oplyste mestre/kunstnere) vil basere sig på realisme eller

12 Spejlmetaforen er dog også del af klassisk, kinesisk chan-buddhistisk diskurs, hvor den i fx Platformsutraen er komprimeret udtryk for både lampe- og spejl-metaforen; oplysningen af sindet, der samtidig er en spejling af altings iboende buddhanatur.

13 At et spejl faktisk viser objektet i sin 'modsatte' form og ligeledes har egenskaben at filtre bølgelængder væk, samtidig med at lys/objekt bibeholder 'oprindelighed', understreger yderligere metaforens relevans. 
empirisme samt antagelsen af 'rødder' (roots), vil spejlmetaforen basere sig på konstruktivisme og antagelsen af ruter (routes). Spejlinger og ruter som metaforer for traditioners udvikling er i forlængelse af, hvad Tweed kalder "hydrodynamics of religion", ifølge hvilke religion ses som "organic-cultural flows" (Tweed 2006, 69). I Vasquez' religionsmetaforer følges (foruden den spatiale med kort og landskab) de 'hydrauliske troper' (flows, bølger, strømme) netop også af modeller for relationer (netværk, spind, stier), da "networks can help us account for mobile religion's flexibility, mobility, connectivity, and innovation" (Vasquez 2008, 179). Urbans Wittgenstein-inspirerede beskrivelse af tantra er dækkende generelt for øst-vest-cirkuleret religion: "a great tangled snarl of crisscrossing strands, or even [..] a great lint ball, comprised of fibers and fragments from a wide range of traditions that make up the religious fabrics of Asia" (Urban 2007, 272).

En meget udbredt metafor for den konkrete asiatiske, religiøse og kulturelle respons på mødet med moderniteten og kolonialismen er Bharatis begreb 'pizzaeffekt'. ${ }^{14}$ Mens hans beskrivelse var baseret på neo-hinduismens vækkelse, har metaforen siden været anvendt også på Dharmapalas vækkelse på Sri Lanka (Prothero 2010) og D. T. Suzuki i moderne Japan (Borup 2004), tæt beslægtet med McMahans betegnelse "feedback effekt" (McMahan 2008, 57). Begge metaforer henviser til kulturelle og religiøse identifikationsprocesser i mødet med en anden kontekst, som i bredere forstand kan få konsekvenser for både individet og dettes pågældende kultur/religion. Peter Beyers metafor med 'halen, der får hunden til at logre' (2007), er således i forlængelse heraf - som i tilfældet med immigranten, der i mødet med den nye kontekst bliver transformeret, og som kan være med til også at få indflydelse på oprindelseslandets kultur og religion. Eksempler med oprindelige kulturers mytologi og ritualer, der indoptager romantiserede new age-traditioners gengivelser af 'de autentiske indfødte', kendes fra især USA, hvor "invention of sacred tradition" (Lewis \& Hammer 2007) er en væsentlig del af udbuddet på det religiøse marked. Processerne kan i det hele taget udvides og gøres endnu mere komplekse med flerfoldige spejlinger og transformationer, som når 'unikke' europæiske filosoffer som Heidegger eller Nietzsche viser sig at have været inspireret af asiatiske tænkere, hvis egne tanker var inspireret af protestantisk religionsforståelse eller teosofiske tanker, der igen var inspireret fra Østen etc. Samtlige metaforer kan læses ind i en konstruktivistisk ramme, der overhovedet nødvendiggør sådanne transformationer. Ligesom identitetsforskningen har påvist identitetskonstruktioner, der har været betinget af grænsedragning til andre ('othering'), vil en sådan videnssociologisk kortlægning kunne fremvise produktion af 'indhold' via konstruerede strukturer.

Men hvad er det da egentlig, der transmitteres? Et post-moderne argument kunne jo netop være, at kun diskurserne om transformationerne eksisterer og har epi-

14 Pizzaen var i Italien en snack, der efter dens import til og transformation i USA blev gen-importeret i dens transformerede udgave som hovedmåltid med diverse fyld, og efterfølgende italesat som en autentisk, italiensk ret. Urbans metafor 'curry-effekten' (Urban 2007, 16) har dog en vis geo-gastronomisk værdi. 
stemologisk gyldighed. Diskurser har naturligvis en væsentlig rolle at spille heri; og på sin vis er diskursteoretiske landvindinger i sig selv en væsentlig del af fundamentet for overhovedet at anskue sådanne transformationsprocesser. ${ }^{15}$ 'Religion' og 'kultur' har måske 'ingen data' og kan problematiseres som ontologiske kategorier; men den performative realitetsværdi. disse kan få via italesættelse og diskursive (trans)formationer, er uomtvistelig og netop interessant. I en post-orientalistisk forstand er der god grund til at dekonstruere 'øst' og 'vest' som en hegemonisk baseret dikotomi uden ontologisk relevans. Men fra et diskursteoretisk, konstruktivistisk perspektiv kan det dog på samme vis påpeges, at både 'øst' og 'vest' (og 'buddhisme', 'hinduisme' etc.) fungerer som begreber, der er italesat og anvendt i praksis, og som således bliver del af en performativ proces, hvis binære oppositioner (og enkeltdele i matricerne) forudsætter og cirkulært transformerer hinanden. Religion er da som kulturelle flows "confluences of organic channels and cultural currents that conjoin to create institutional networks that, in turn, prescribe, transmit, and transform tropes, beliefs, values, emotions, artifacts, and rituals" (Tweed 2006, 69). Som tantra er øst-vest-cirkuleret religion udtryk for et "tangled web of intersecting threads, both Eastern and Western, ancient and modern, woven through the intricate cross-cultural interplay of scholarly and popular imagination" (Urban 2007, xiii).

De elementer, der i en sådan øst-vest transformativ cirkulation har vist sig relevante som med-konstituerende faktorer og katalysatorer, kan kategoriseres som hhv. aktører, praksis/lære og kontekst. Til aktørniveauet har det vist sig, at konkrete netværk af personer har haft kolossal indflydelse på også bredere religiøse transformationer. Disse har inkluderet markante, vestlige tænkere, hvis inspiration fra Østen har været betydningsfuld for egen udvikling af tanker. Hertil kunne også indskrives de religiøse netværk, der som dialoginitiativer har haft betydning for de enkelte religioners selvforståelse og udvikling. ${ }^{16}$ Konkret har især det Teosofiske Selskab været betydningsfuld for den hinduistiske og buddhistiske vækkelse i sidste del af det nittende århundrede, ligesom moderne new age og spiritualitet og i samtiden ikke mindst karismatiske buddhister som Dalai Lama, Thich Nhat Hanh samt forskellige indiske guruer har høstet en god del inspiration fra en sådan moderne 'Easternization' proces. ${ }^{17}$

Den kulturelle og socio-politiske historiske kontekst er en nødvendig ramme til overhovedet at muliggøre og realisere sådanne 'glokale' møder. Sådanne kontekster

15 En ekskurs til buddhistisk filosofi kunne imidlertid her være berettiget til anskueliggørelse af problemfeltet. En grundfilosofisk antagelse er her, at intet eksisterer 'i sig selv'. Alt er at forstå som midlertidigt eksisterende konfigurationer af elementer, hvis indbyrdes relationer konstituerer en (om end ikke absolut, så dog relativ) erkendbar virkelighed, nogle gange illustreret med Indras net, hvis netværk er forbundet med i hinanden afspejlede juveler. Hvorvidt modellen som matrice skal forstås som et grundlæggende ontologisk princip, er på sin vis irrelevant for såvel buddhistisk lære (hvor praksis frem for metafysik ofte påberåbes) som anskueliggørelse af de her beskrevne transformationsprocesser.

16 For eksempler på sådanne personer og netværk, se Borup 2013.

17 Rawlinson 1997 giver en fin oversigt over betydningsfulde 'enlightened masters' fra både øst og vest og ikke mindst de netværk, disse har indgået i. 
er medkonstituerende for, på hvilken måde og under hvilke strategier, møder med Vesten og (post)moderniteten har udviklet sig. Disse kan være konkrete milepæle, som World Parliament of Religions i Chicago 1893, eller de kan være generelle rammebetingelser, som kolonialisering. Østens post-koloniale udfordringer har naturligvis været indbyrdes forskellige, og haft forskellige udkommer. Men især hinduismens og buddhismens narrativer har vist sig at have konstruktive implikationer, der synes at have vundet genklang via spejlede transformationsprocesser i både øst og vest. Også i moderne tid synes sådanne rammer at have givet disse gode vækstmuligheder. Det gælder både for immigranter fra Asien og for de asiatiske kultur- og religionsnarrativer, at de især i en meditaliseret virkelighed har passet godt ind i en vestlig narrativ. Det gælder også de østlige elementer, der i en samtidig markedsorienteret, post-sekulær virkelighed har været med til at 'sælge spiritualitet' (Carrette \& King 2005). 'Asiatiske værdier', 'soft power' og kinesisk vækkelse af konfucianismen som fundamental kulturbaggrund for økonomisk vækst er således eksempler på relevansen af socio-økonomiske rammer for moderne religionsdiskurser.

Det er dog heller ikke ubetydeligt, hvilket 'produkt', der har været udvundet og udviklet i den transformative proces. Religiøse, transnationale traditioner skal for at få en vis succes både "(1) disseminate an attractive cross-border message; while (2) adapting to local circumstances" (Haynes 2012, 14). Især hinduisme og buddhisme, men også daoisme og østasiatisk folkereligiøsitet har ofte været beskrevet som åbne og 'brugbare' med ideer og praksisformer, der med Csordas ord kan siges at være både 'transportable' og 'transponerbare' (Csordas 2009, 4-5). Det har dog vist sig, at det er helt konkrete ideer og helt konkrete praksisformer, der har fundet vej fra øst til vest. Det er således ikke den ellers allermest udbredte form for østasiatisk religion, forfædredyrkelse, der er kommet hertil, ej heller salg af amuletter eller divinatoriske teknikker. Typisk har det i både modernitets- og post-modernitetsuniverser været ideer og praksisformer, der har relateret sig direkte til rationalitets- og spiritualitetsdiskurserne. Begge er dybt indlejret i individualiseringsregimer, der er en del af en generel modernitetsproces, og som ikke desto mindre også har medført forskydninger og udpenslet grænser for 'semantiske udstrækninger'. Især meditation har været et sådan ritual, der på den ene side i sin typisk vestlige anvendelse fint illustrerer såvel rationalitets- som spiritualitetsparadigmerne på tværs af øst og vest, men som alligevel har undergået ganske betydelige forandringer. Det giver mening i en moderne og især vestlig kontekst, at zen-meditation integreres også inden for Rene Lands-buddhisme, der traditionelt ikke har haft meditation som del af praksis (Dessi 2013, 70ff.). Reinkarnation og karma synes også at passe godt til moderne, vestlig og neo-liberal kultur. Begrebernes indhold er blevet transformeret, men er selv i et cirkulært transformationsperspektiv med til at konstruere nye rammer for betydning og praksis. Mindfulness har i den forstand også undergået en åbenlyst naturlig transformation fra at være et klosterbaseret ritual (blandt mange andre) for eliten til at blive en buddhisme- og religions-transcenderende spirituel eller sekulær teknik for 
de mange. Det vil være interessant at følge, om en sådan udvikling også i fremtiden vil vise sig i asiatiske samfund med stigende individualisering.

\section{Konklusion}

Det interessante ved analyser af religiøse transformationsprocesser er ikke at 'afsløre' traditioner som opfundne og konstruerede. I en vis forstand kan en sådan operation gøres med alle kulturelle og religiøse traditioner, der i en eller anden forstand er transformationer af andre traditioner (og således 'opfundne'). Det udfordrende er at anskue, hvordan cirkulationerne er konstitueret, og med hvilke udtryk, de manifesterer sig. Røddernes og ruternes transformationer som cirkulationer, der baserer sig på og får eksistensberettigelse ved møder og spejlinger er således udtryk for en generel, på sin vis ganske ukontroversiel, religionshistorisk erfaring. Religioner og kulturer forandrer sig i mødet med andre, og opfundne traditioner og konstruktioner har konkrete effekter. Essentialiseringer og autenticitetskonstruktioner er reelle, og har effikacitet!

I et bredt religionshistorisk perspektiv har sådanne cirkulationer haft forskellige vilkår og udbredelse. En mulig genealogisk udveksling (og mulig konvergent udvikling) mellem øst og vest i aksetidstransformationen er et endnu ikke fuldt belyst, men dog ganske væsentligt, felt, hvis udbredelse dog må siges at være begrænset til en eliteminoritet. I den lange periode frem til det 18. århundrede var de transformative spring sporadiske, men ikke uvæsentlige for den periode, der har haft størst betydning og forskningsmæssig bevågenhed, nemlig moderniteten. Denne var præget af en kolonialistisk vestliggørelse med stor effekt for asiatiske religioner, men også af en respons med effekt den modsatte vej. Modernitetens religiøse cirkulationer var stadig mest for eliten, men med langt bredere geografiske og historiske effekter. Cirkulationen fortsætter i dag, men med væsentlige forskydninger; magtcentrum er ændret, og eliten har fået selskab af masserne. Man kan for alvor tale om (i hvert fald konturerne for) transkulturelle cirkulationer med global betydning.

Kommende forskning indenfor disse rammer vil kunne tydeliggøre sådanne cirkulationsprocesser såvel i historisk som i nutidsperspektiv. Det vil i sig selv være interessant med analyse af endnu flere konkrete, empiriske tilfælde, i hvilken narrativer og praksisformer i synkront og genealogisk relaterede netværk har udviklet sig. Der er allerede analyseret konkrete praksisformer (yoga, meditation), men også andre fænomener (som feng shui, ayurveda, alternativ medicin, kampkunst etc.) kan være med til at belyse og uddybe cirkulære transformationsprocesser. Det er dog givet, at sådanne også vil kunne destilleres uden for den her skitserede øst-vest arena, i hvilken vestlige (kulturelle, religiøse) rammefortællinger via konkrete netværk og ruter vil kunne anskues i deres cirkulations-transformatoriske universer. Ikke mindst $\mathrm{i}$ et transnationalt og globalt perspektiv vil sådanne transformationskanaler og -strukturer være relevante at undersøge. Hvordan, af hvem og hvorfor bliver 
anden-generationskultur og -religiøsitet transformeret, og hvilken relevans har det for oprindelseslandet, at 'halen får hunden til at logre'? Ikke mindst i en moderne, identitets- og autenticitetsidealiserende kultur vil analyser af sådanne ruter være interessant til belysning af cirkulære autenticitetskonstruktioner, der går bagom både universalistisk essentialisering og postmoderne partikularisme. Nærværende bidrag skal således ses dels som en analyse af et (ganske vist meget bredt) konkret empirisk baseret felt, dels som et forslag til et teoretisk perspektiv, hvis udfoldelse er åben for yderligere inspiration.

\section{LITTERATUR}

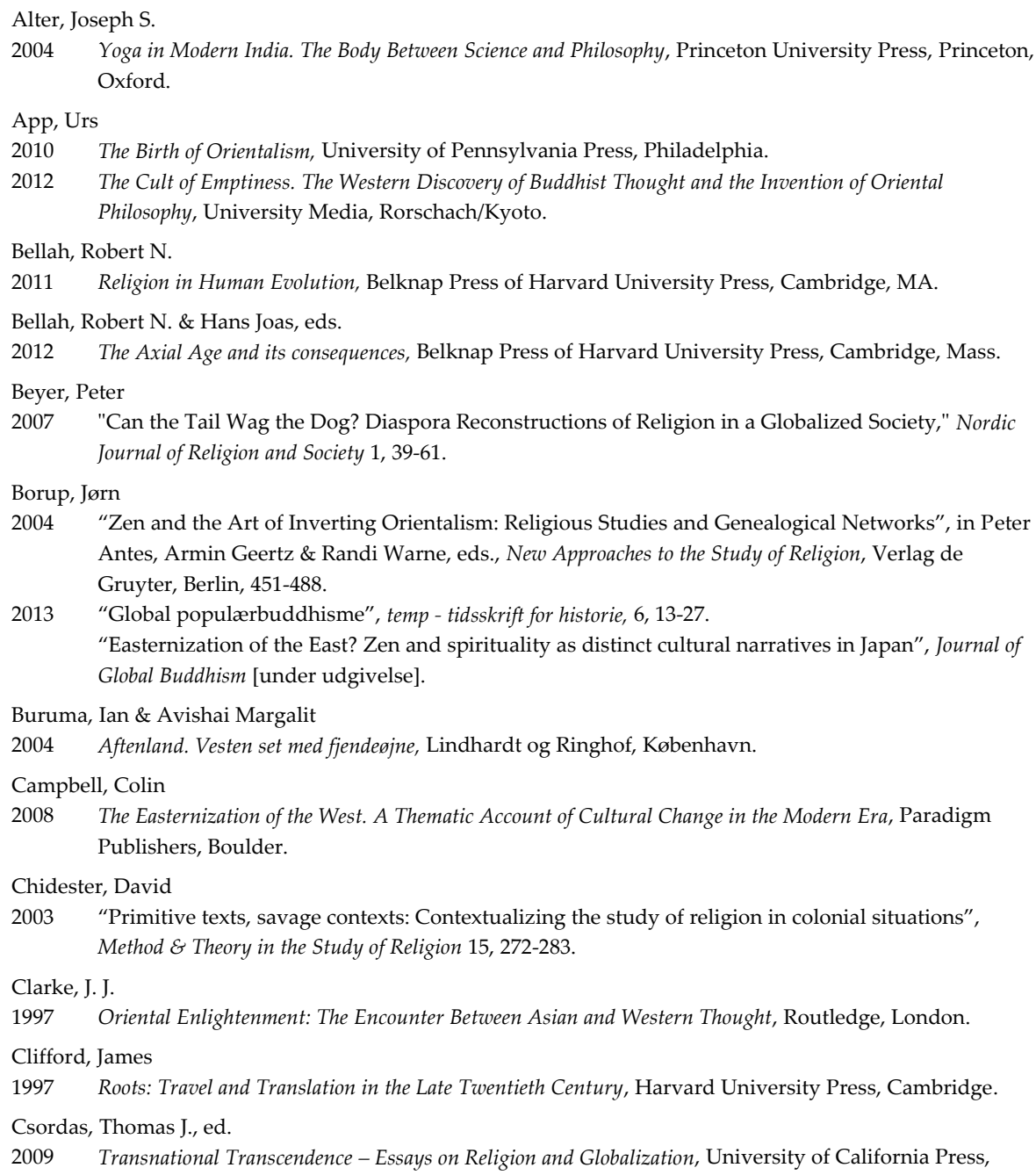


Berkley.

Dessi, Ugo

2013 Japanese Religions and Globalization. Routledge, Abingdon \& New York.

Duara, Prasenjit

2010 "Asia Redux: Conceptualizing a Region for Our Times", in: The Journal of Asian Studies 69 (4), 963983.

Frøystad, Kathinka

2009 "The return path. Anthropology of a Western yogi", in: Thomas Csordas, ed., Transnational Transcendence: Essays on Religion and Globalization, University of California Press, Berkeley, 279-304.

Gombrich, Richard \& Gananath Obeyesekere

1988 Buddhism Transformed: Religious Change in Sri Lanka, Princeton University Press, Princeton, New Jersey.

Goody, Jack

1996 The East in the West, Cambridge University Press, Cambridge.

Lewis, James R. \& Olav Hammer, eds.

2007 The Invention of Sacred Tradition, Cambridge University Press, Cambridge.

Haynes, Jeffrey

2012 Religious Transnational Actors and Soft Power, Ashgate, London.

Heelas, Paul \& Linda Woodhead

2005 The Spiritual Revolution. Why Religion is giving Way to Spirituality, Oxford Blackwell Publishing, Oxford.

Hinde, John R

2012 "Ricardo Duchesne: The Uniqueness of Western Civilization", Canadian Journal of History 47 (1): 193195.

Hobson, John M.

2004 The Eastern Origins of Western Civilisation, Cambridge University Press, Cambridge.

Joo, Ryan Bongseok

2011 “Countercurrents from the West: 'Blue-Eyed' Zen Masters, Vipassana Meditation, and Buddhist Psychotherapy in Contemporary Korea", Journal of the American Academy of Religion 79 (3), 614-38.

King, Richard

1995 Orientalism and Religion: Post-Colonial Theory, India and "The Mystic East", Routledge, London.

King, Richard \& Jeremy Carrette

2005 Selling Spirituality: the Silent Takeover of Religion, Routledge, London.

Lach, Donald F.

1994 Asia in the making of Europe - volume I, The Century of Discovery (two books); volume II, A Century of Wonder (three books), University of Chicago Press, Chicago.

Lach, Donald F. \& Edwin J. van Kley

1998 Asia in the making of Europe, volume III, A Century of Advance (four books), University of Chicago Press, Chicago.

Larson, Gerald James \& Eliot Deutsch, eds.

1989 Interpreting Across Boundaries: New Essays in Comparative Philosophy, Motilal Banarsidass, Delhi.

Lee, Raymond L. M.

2003 "The Re-enchantment of the Self: Western Spirituality, Asian Materialism", Journal of Contemporary Religion 18 (3), 351-367.

Lewis, James R. \& Olav Hammer, eds.

2007 The Invention of Sacred Tradition, Cambridge University Press, Cambridge.

McMahan, David L.

2008 The Making of Modern Buddhism, Oxford University Press, Oxford. 
McNeill, J. R. \& William H. McNeill

2003 The Human Web: A Bird's-Eye View of World History, W. W. Norton \& Company, New York.

Nair-Venugopal, Shanta

2012 "Introduction", in: Shanta Nair-Venugopal, ed., The Gaze of the West and Framings of the East, Palgrave Macmillan Basingstoke, Hampshire, 3-25.

Nederveen Pieterse, Jan

2006 "Oriental Globalization", Theory, Culture \& Society 23, 411-413.

Newcombe, Suzanne

2012 "Global Hybrids? Eastern Traditions of Health and Wellness in the West", in: Shanta NairVenugopal, ed., The Gaze of the West and Framings of the East, Palgrave Macmillan Basingstoke, Hampshire, 202-217.

Prothero, Stephen

2010 The White Buddhist: The Asian Odyssey of Henry Steel Olcott, Indiana University Press, Bloomington.

Rawlinson, Andrew

1997 The Book of Enlightened Masters. Western Teachers in Eastern Traditions, Open Court, Chicago and La Salle.

Sharf, Robert

1995 "Buddhist Modernism and the Rhetoric of Meditative Experience", Numen 42, 228-83.

Singleton, Mark

2010 Yoga Body: The Origins of Modern Posture Practice, Oxford University Press, Oxford.

Tweed, Thomas A.

2002 "Who Is a Buddhist? Night-Stand Buddhists and Other Creatures", in: Charles S. Prebish \& Martin Baumann, eds., Westward Dharma: Buddhism Beyond Asia, Berkeley, University of California Press 1733.

2006 Crossing and Dwelling: A Theory of Religion, Harvard University Press, Cambridge, MA.

Urban, Hugh B.

2007 Tantra - Sex, Secrecy, Politics, and Power in the Study of Religion, Motilal Banarsidass Publ., Delhi [orig. University of California Press, Berkley 2003].

Van der Veer, Peter

2009 "Spirituality in Modern Society" in: Society Social Research 76 (4), 1097-1120.

Van der Veer, Peter

2014 The Modern Spirit of Asia. The Spiritual and the Secular in China and India, Princeton University Press, Princeton.

Vásquez, Manuel A.

2008 "Studying Religion in Motion: A Networks Approach", Method and Theory in the Study of Religion 20, 151-184.

Jørn Borup, lektor, ph.d. Religionsvidenskab, Aarhus Universitet 